\title{
Assessment of hazards in local soy-cheese processing: implications on health and environment in Oyo State, Nigeria
}

\author{
S. B. Fasoyiro \\ Institute of Agricultural Research and Training, Ibadan, Nigeria
}

\begin{abstract}
This study was carried out to assess the hazards associated with the processing of soy-cheese in Oyo State, Nigeria. Soy-cheese is a cheese-like product from soybean, rich in nutrients and often eaten as a substitute for meat. Soy-cheese processing is an important source of income generation for many women processors in south-west Nigeria. Thirty local processors were interviewed using structured questionnaire. Information obtained from the processors include: types of waste generated, means of disposal, types of hazards processors are exposed to during processing, any previous training in food safety. The processing operations were also observed for possible hazards and their sources. Results of the study show that hazards in soy-cheese processing include physical, chemical and occupational apart from microbial types. Both liquid and solid wastes were generated during the production process. Almost all the processors $(96.7 \%)$ disposed solid waste by bush burning causing environmental pollution. Processors were often faced with the challenge of cuts, burns, smoke and free radicals during processing which has its health implications. The study is expected to bring a follow-up training in educating the local processors on the implications of their activities on health and the environment.
\end{abstract}

Keywords: soy-cheese, processors, hazards, environment, health implications.

\section{Introduction}

Soy-cheese is a popular product from soybean which is cheese-like in taste. In the Orient, it is called tofu while in Nigeria, it is called soy-warankashi. It is rich in protein and fat and it is highly digestible (Kale [1]). It has been used as meat and cheese substitute in both rural and urban areas of south west Nigeria. Local 
processing of soy-cheese is usually done at the home-level requiring little or no sophisticated equipment. Different methods of local processing of soy-cheese have been described in literature based on the use of local coagulants by Aworh and Nakai [2]. This product after production is often sold on the streets.

Soy-cheese processing is a common enterprise among women both in rural and urban communities in Oyo State, Nigeria. The enterprise is often run as a sole business in some families whereas some utilize food processing as a diversified means of income generation and for household food security by Babatunde and Quaim [3]. High level of unemployment rate due to poverty has increased the number of people especially women involved in processing and street-vending of foods as a means of livelihood for sustenance of their families.

Soy-cheese, although a valuable product in meeting the nutritional requirement for improved intake of quality protein in both children and adult, it is however often processed under poor hygienic conditions. Fresh soy-cheese is a high risk food because it is high in protein, moisture and fat contents which makes it highly susceptible to microbial attack. In addition, it can become easily contaminated through poor handling. Concerns over the safety of home-made street-vended foods has increased because of food borne diseases and health risks associated with their consumption. Street-vended foods have been reported by AFRO Food Safety Newsletter [4] to pose health risks particularly to the young, the elderly and those living with HIV/AIDS. There have been reported cases of food poisoning after consumption of street foods. Centre for Disease Control and Prevention [5] reported the case of botulism from consumption of home-prepared tofu. Food safety issues have both public health and environmental implications. It is related to poverty, a multi-dimensional issue which is not just about inaccessibility to nutritionally adequate food but also to food hazards. Food hazards are associated with low income, poor accessibility to safe practices which leads to vulnerability and disempowerment. An earlier study by Fasoyiro et al. [6] reported on the microbial hazards and critical control points in local soy-cheese processing. The processing situation is worsened by lack of electricity, safe potable water, public health education and sanitation services.

This study reports on identified hazards apart from microbes associated with soybean processing in Oyo State and their implications on health and the environment.

\section{Materials and methods}

\subsection{Selection of study area}

Local processors were selected from Alakia, Apata and Bodija areas of Ibadan, Nigeria. The areas were selected on the basis of high density of soy-cheese processors concentrated in these areas. Thirty women were randomly selected for this study. 


\subsection{Assessment of hazards in soy-cheese processing}

Processors were visited prior to the study to seek their consent in participating in the study. Observations were made on noticeable sources of physical, chemical and occupational hazards during the production operations of soy-cheese. Main soy-cheese processing operations involve: washing of soybean seeds, soaking of soybean seeds, milling, filtering with cheesecloth, addition of coagulant (fermented maize liquor or alum solution), boiling, straining, pressing and frying. Structured interview schedule was also used in collecting data on: whether processors utilize soy-cheese processing as main source of income, the number of years spent in soy-cheese processing, types of waste generated during processing, means of waste disposal, types of occupational hazards processors are exposed to during processing, any previous training in food safety. The interview schedule was administered to the selected processors between February and May, 2008. Descriptive statistical tool (percentages) was used in analyzing the data.

\section{Results and discussion}

The attributes of the respondents are shown in Table 1 . The processors $(76.6 \%)$ were involved in soy-cheese processing as their sole business while others are involved in other petty businesses in generating income for their household sustainability. Some of the respondents have spent up to 10 years in soy-cheese processing. Out of all the respondents interviewed, only $6.67 \%$ has training in food processing while none of them have been trained in food safety practices.

Table 1: $\quad$ Characteristics of respondents.

\begin{tabular}{|c|c|}
\hline Characteristics of respondents & Percentage of respondent (\%) \\
\hline Soy-cheese as main business & 76.7 \\
\hline Years in soy-cheese business & 13.3 \\
$\leq 1$ year & 26.7 \\
$<5$ years & 33.3 \\
$\mathbf{5 - 1 0}$ ears & 26.7 \\
$>10$ years & 6.67 \\
\hline Training in food processing & nil \\
\hline Training in food hygiene/ safety & \\
\hline
\end{tabular}

Table 2 shows the physical and chemical hazards in local soy-cheese processing. Physical contaminants include stones and soils from improperly sorted seeds, pressing operation and drawn well water. Soy-cheese pressing was done by putting the drained soy-cheese inside cheesecloth and pressing on 
between stones for dewatering. Small stones were noticeable in some soy-cheese samples. Derici et al. [7] reported that stones have been implicated with appendicitis as a result of stones in the gall bladder. This in human health could lead to surgery with its economic implications. Water used for processing was obtained directly from the well and used without prior treatment. In a previous study by Fasoyiro et al. [6], some microorganisms found in water samples used in soy-cheese preparation, the coagulant and the soy-cheese samples were reported (Table 3). Poor unhygienic practices of the handlers is a major means of microbial contamination of the product through exposure of processing materials and products to dust and dirts apart from using untreated water. Soy-cheese processors prepare soy-cheese in open places. Food borne disease due to intake of contaminated foods have been implicated in causing either food infections or food intoxication. Food infections involve microorganisms present in the food at the time of consumption which then grow in the host and cause illness and disease. Food intoxication on the other hand involves toxic substances produced in the food as a by-product of microbial activities prior to consumption and cause disease upon ingestion (Potter and Hotchkiss [8]). Staphylococcus aureus has been implicated in producing bacterial food poisoning by intoxication. Aspergillus flavus produces mycotoxin (Aflatoxin). Mycotoxins may be carcinogenic, mutagenic, teratogenic and immunosuppressive. Aflatoxin

Table 2: $\quad$ Physical and chemical hazards in soy-cheese processing.

\begin{tabular}{|c|c|}
\hline Hazards & \multirow{2}{*}{$\begin{array}{c}\text { Possible sources of contamination } \\
\text { Physical contaminants }\end{array}$} \\
\hline Stones, soils & $\begin{array}{r}\text { Seeds, water } \\
\text { Chopping boards, trays, utensils, } \\
\text { cheesecloth }\end{array}$ \\
\hline Dust, dirts & Continuous re-use of frying oils \\
\hline Chemical hazards & Coagulant \\
\hline Free radicals, oxidation compounds & Knives, trays \\
\hline Aluminum sulphate & $\begin{array}{c}\text { Newspapers used as packaging } \\
\text { materials }\end{array}$ \\
\hline Iron (metal) rusts & Ink \\
\hline
\end{tabular}

Table 3: $\quad$ Some microorganisms detected during soy-cheese processing.

\begin{tabular}{|c|c|}
\hline Sources & Microorganisms \\
\hline Water samples & $\begin{array}{c}\text { Streptococcus sp, Staphylococcus sp. } \\
\text { Bacillus cereus, Escherichia coli }\end{array}$ \\
\hline Coagulant (Fermented maize liquor) & Aspergillus sp, Rhizopus sp \\
\hline Soy-cheese samples after frying & $\begin{array}{c}\text { Streptococcus } s p \text {, Staphylococcus } s p . \\
\text { Bacillus cereus, Escherichia coli, } \\
\text { Aspergillussp, Rhizopus sp }\end{array}$ \\
\hline
\end{tabular}

Source: Fasoyiro et al. [6] 
exposure in children has been associated with child stunting and neurological impairment [4]. Escherichia coli is a faecal coliform. Symptom of microbial infection or intoxication can range from vomiting, diarrhoea, intestinal cramps to more complicated cases and death. Study on food habit has shown that children are important street food consumers [4], hence they form big target for these hazards

Some processors utilized aluminum sulphate solution without standards as coagulant for precipitation of soybean paste slurry. This is used as an alternative to fermented maize liquor. There is still no adequate information or literature on the safety of consumption of aluminium sulphate. However, Evert et al. [9] reported on possible effects such as dementia from consumption of aluminium sulphate. Other noticeable hazards are iron rust from knives and aluminium coated iron trays used in cutting soy-cheese of some processors. Ink is also a chemical hazard detected from the packaging material. All of the processors uses old newspaper as packaging material for soy-cheese. There is the need to discourage this practice among the processors. The processors usually sell their products around their homes and on the street, the packaging materials after consumption by the consumers were used in littering the surroundings without proper disposal means. Local soy-cheese is usually sold in fried forms. All the processors re-used the frying oil from a previous frying process. This is usually for eight to ten times till it is discarded due to dark colour. Frying is usually carried out using large iron wrought frying pans on open fire. The frying operation that takes place at very high temperatures. During frying, oxidative reactions involving the formation of and decomposition of hydroperoxides occur which leads to formation of compounds such as ketones, hydrocarbons, acids and esters (Fennema [10] and Pambou-Tobi et al. [11]). Darkening of frying oils due to oxidation products is noticeable in the reused frying oils. Products of lipid oxidation has been implicated in development of carcinogens [10 ].

The waste products generated during soy-cheese processing and their means of disposal is shown in Table 4. Waste generated during soy-cheese processing can be classified as solid and liquid wastes. One of the solid wastes generated is Okara, this is the product removed after sieving the soymilk from the grinded paste slurry. Some of the respondents $(16.7 \%)$ however indicated that they utilize the Okara in animal feeding while the others discarded it as waste. Research has shown that Okara is rich in protein and it has also been utilized in food fortification of maize by Omueti [12]. This will be useful in improving the nutritional status of the poor resource people. Other waste products include packaging materials in form of newspapers and polyethylene bags. Almost all the processors $(96.7 \%)$ disposed solid wastes by burning. Refuse burning leads to production of smoke and emission of gases causing air pollution. This promotes acid rain which pollutes the land and water with implications on human, terrestrial lives and the vegetation. Air pollution also contributes to global warming due to depletion of the ozone layer (Daramola and Ibem [13]). Fermented maize liquor is the common coagulant used in soy-cheese processing. It is fermented water from processing maize into a product called Ogi. The processors either collect the liquor from $O g i$ processors or prepare $O g i$ by 
themselves to obtain the fermented liquor. Excess fermented liquor not utilized in a day was either poured into gutters or dumped into open vegetation. Dark oil from frying process was disposed in a similar way as the fermented liquor.

Table 4: $\quad$ Types of waste generated during soy-cheese processing and means of disposal.

\begin{tabular}{|c|c|}
\hline Solid waste (Source) & Means of disposal \\
\hline $\begin{array}{c}\text { Okara } \\
\text { Paper (packaging material) } \\
\text { Polyethylene film (packaging } \\
\text { material) }\end{array}$ & $\begin{array}{c}\text { Used as animal feed, directly on } \\
\text { open vegetation } \\
\text { By burning } \\
\text { By burning }\end{array}$ \\
\hline Liquid waste & \\
\hline $\begin{array}{c}\text { Wash water (from washed and soaked } \\
\text { seed) } \\
\text { Fermented maize liquor (excess } \\
\text { coagulant) } \\
\text { Dark Oil (from continuous frying } \\
\text { process) }\end{array}$ & $\begin{array}{l}\text { Direct dumping to open vegetation } \\
\text { and gutters } \\
\text { Direct dumping to open vegetation } \\
\text { and gutters } \\
\text { Direct dumping to open vegetation } \\
\text { and gutters }\end{array}$ \\
\hline
\end{tabular}

Table 5 highlights the occupational hazards encountered by the soy-cheese processors. Local processors generally utilize firewood in cooking. The firewood generates smoke which contact the processors eyes. Smoke is reported to cause irritation to the eyes, nose and throat, Betchley et al. [14].The long term effect of the smoke could result in eye disorders. All the processors interviewed opted for the use of firewood as a cheaper means of cooking compared to use of kerosene stove or cooking gas. Continuous cutting of trees for the purpose of firewood is not only affecting the environmental health by depleting the natural resources but also contributes to global warming and climate change. Processors $(13.3 \%)$ sometimes sustained injuries such as cut fingers during cutting of cheese since

Table 5: $\quad$ Occupational hazards faced by soy-cheese local processors.

\begin{tabular}{|c|c|}
\hline $\begin{array}{c}\text { Occupational hazards (frequency of } \\
\text { respondents) }\end{array}$ & Sources \\
\hline $\begin{array}{c}\text { Eyes in contact with firewood smoke } \\
(73.3 \%)\end{array}$ & From firewood used in cooking \\
\hline Cuts, bleeding (53.3\%) & From knives \\
& While pushing firewood into the fire \\
\hline Burns $(40 \%)$ & Hot oil splashes during frying \\
\hline
\end{tabular}


it is manually done which results in bleeding. This could also lead to product contamination. Injury from wood piercing of fingers while pushing the wood into the firewood was also recorded. Accidental oil splashes often occur while frying soy-cheese which often results in skin burns.

\section{Conclusion}

This study reported some of the hazards that are encountered during soy-cheese processing. It also reflects how small scale food processing which forms an integral part of the Nigerian economy can affect human and environmental health through ignorance of processors on implications of their activities. The following are therefore recommended as strategies to reduce some of the problems identified in local food processing:

-the need for training of local processors on food safety practices to sensitize and create awareness on possible hazards and their implications on human and environmental health

-the need for food law enforcement agencies to have standards for locally processed foods and to ensure they are implemented

-the need for the environmental law enforcement agencies to have waste disposal standard for small scale processors.

\section{Acknowledgement}

USDA Borlaug Women-in-Science Research Grant is acknowledged for supporting this study.

\section{References}

[1] Kale F.S. Soybean, its values in dietetics, cultivation and uses. J.D Jain Publishers: Delhi, pp.420,1985.

[2] Aworh O.C \& Nakai S. Extraction of milk clotting enzyme from Sodom apple (Calotropis procera). Journal of Food Science 51(6), pp. 1569-1570, 1986.

[3] Babatunde R.O \& Quaim M. Patterns of income diversification in rural Nigeria: determinants and impacts. Quarterly Journal of International Agriculture 48(4), pp.305-320, 2009.

[4] AFRO Food Safety Newsletter. Street food vending in the region: Food safety challenges. World health Organization food safety (FOS), (2), pp. 15, 2006.

[5] Centre for Disease Control and Prevention (CDC). Food borne botulism from home-prepared fermented tofu-California 2006. Morbidity and Mortality Weekly Report, 56(5), 96-97, 2007.

[6] Fasoyiro S.B, Obatolu V.A, Ashaye O.A, Adegoke G.O \& Farinde E.O. Microbial hazards in locally processed soy-cheese in Nigeria. Nutrition and Food Science 40(6), pp.591-597, 2010. 
[7] Derici H, Kara C, Bozdag A.D, Nazli O, Tansug T, Akca E. Diagnosis and treatment of gallbladder perforation. World Journal of Gastroenterology. 12(48), pp. 7832-7836, 2006.

[8] Potter N.N and Hotchkiss. J.H. Food Science. Fifth Edition. Springer USA. pp.119-120, 1998.

[9] Evert N., Gibson B.L, Oxman A.D \& Kramer J.R. Health effects of aluminum: a critical review with emphasis on aluminum in drinking water .Environmental Review 3, pp. 29-81, 1995.

[10] Fennema O.R. Food Chemistry. Third edition. Taylor and Francis Group. New York. pp.292-295, 1985.

[11] Pambou-Tobi N.P, Nzikou J.M, Matos L., Ndangui C.B, Kimbonguila A. , Abena A.A, Silou T., Scher J. \& Desobry S. Comparative Study of Stability Measurements for Two Frying Oils: Soybean Oil and Refined Palm Oil. Advance Journal of Food Science and Technology 2(1), pp. 22-27, 2010

[12] Omueti O. Home level preparation of protein improved (soya kokoro-maize snack). Tropical Oil Seed Journal4, 95-101, 1999.

[13] Daramola A. \&Ibem E.O. Urban environmental problems in Nigeria: implication in sustainable development. Journal of Sustainable Development in Africa 12(1), pp.124-145, 2010.

[14] Betchley C., Koenig J.Q., Vanbelle G., Checkoway H., Reinhardt T., Pulmonary Function and Respiratory Symptoms in Forest Firefighters. American Journal of Industrial Medicine 31(5), pp.503-509, 1997. 